\title{
Measurement and analysis of vibrations - Evaluation of the criteria of acceptance ISO Standard 10816-6
}

\author{
Medición y análisis de vibraciones - Evaluación del criterio de aceptación Norma ISO 10816-6.
}

DOI: https://doi.org/10.25043/19098642.196

Roger Arévalo Gómez ${ }^{1}$

\begin{abstract}
During the reception and / or delivery tests of a ship, vibration measurement and analysis is made to the propulsion line in order to evaluate and predict the condition of the machinery. The values taken during the measurement of the vibrations are evaluated with the acceptance criteria provided by the standards. International Standard ISO 10816-6 (1995) focuses on reciprocating machinery with power of greater than $100 \mathrm{~kW}$, is used by both analysts and manufacturers of propulsion machinery for ships. Through this work, we intend to evaluate the acceptance criteria of this norm in boats smaller than 100 meters. At the end of this work it is concluded that the standard must be updated, indicating and differentiating the acceptance criteria for machinery taking into account its type of anchorage to the structure (flexible or rigid), boats with length less than or greater than 100 meters and the Ship building material (Aluminum, Steel or Composite material).
\end{abstract}

Key words: Reciprocant, Vibration level.

\section{Resumen}

Durante las pruebas de recepción y/o entrega de un buque se realiza medición y análisis de vibración a la línea de propulsión con el fin evaluar y predecir la condición de la maquinaria. Los valores tomados durante la medición de las vibraciones son evaluados con los criterios de aceptación que entregan las normas. La norma Internacional ISO 10816-6 (1995) se enfoca en la maquinaria reciprocante con potencia de rateo mayor a $100 \mathrm{~kW}$, es utilizada tanto por analistas como por fabricantes de maquinaria propulsiva para buques. Por medio de este trabajo se pretende evaluar los criterios de aceptación de esta norma en embarcaciones menores a 100 metros. Al final de este trabajo se concluye que la norma debe ser actualizada, indicando y diferenciando los criterios de aceptación para maquinaria teniendo en cuenta su tipo de anclaje a la estructura (flexible o rígida), embarcaciones con eslora inferior o superior a 100 metros y el material de construcción del buque (Aluminio, Acero o Material compuesto).

Palabras claves: Reciprocante, nivel de vibración.

Date Received: January $17^{\text {th }} 2019$ - Fecha de recepción: Enero 17 de 2019

Date Accepted: March 3 2019 - Fecha de aceptación: Marzo 3 de 2019

${ }^{1}$ COTECMAR. Cartagena, Colombia. Email: rarevalo@cotecmar.com 


\section{Introduction}

ISO 10816-6 "Mechanical vibration - Evaluation of machine vibration by measurements on nonrotating parts - Part 6: Reciprocating machines with power ratings above $100 \mathrm{kW"}$, specifies the conditions and general procedures for the measurement and evaluation of the linear vibrations, in measurements made on the nonrotating parts of reciprocating machines with powers greater than $100 \mathrm{~kW}$.

Typical examples of application are marine propulsion engines, Diesel engine generator sets, gas compressors and diesel engines for locomotives. This standard does not apply to machines installed on road vehicles.

ISO 10816-6 in Annex A "Classification of vibration in machinery" indicates a qualification of reciprocating machinery. In said classification, the standard establishes that diesel and industrial marine engines can be classified either 5,6 or 7 .

Since 2013, COTECMAR has acquired the technological and human capacity to carry out with its own force the measurement and analysis of the linear vibrations of the ships belonging to the Colombian Republic Navy (ARC) and private customers.

In these more than four years the experience in the measurement and analysis of linear vibrations in the propulsion lines of ships has been strengthened, which includes an internal combustion engine, a power transmission box and revolutions to the transmission shaft and finally to the propeller.

In more than 63 ships served in this period (2013 to 2018) measurements and analysis of linear vibrations were made to diesel engines of $A R C$ and private vessels, totaling approximately 150 services. At the beginning there were many inconveniences and complaints from the client because although the global vibrations did not reach the minimum level, level 5, required by ISO 10816-6 to consider an alarm in the diesel machinery, in reality, there were developments in the engines, which affected the credibility of the client.
Therefore, it was determined to reclassify the machinery at least to level 3 indicated by the standard. By doing this, we had a more accurate alarm of the novelties presented by the diesel machinery and determined through the measurement and analysis of linear vibrations.

\section{Presentation of the problem}

Before COTECMAR, had the ability to meet the service of measurement and analysis of vibrations lines with its own strength, this was executed by means of contractors, local companies specialized in measurement and analysis of vibrations, but who did not have the knowledge in the area ship, the behavior of the marine combustion machinery and the standards used by these companies were not adequate.

The ignorance in the behavior in marine diesel machinery and the lack of use of an adequate norm in multiple occasions caused complaints and complaints on the part of the final client due to a bad concept or conclusion on the part of the analyst.

By training personnel in the naval area, certifying it in vibration analysis under the guidelines of ISO $18436-2$ in level II and acquiring equipment for the measurement and subsequent analysis of the linear vibration measurement, gave COTECMAR a better answer. customers, reducing the number of complaints and claims, which was seen in a significant increase in the number of services that went from 9 in 2014, 42 in 2015, 46 in 2016, 40 in 2017 and 46 services in 2018.

For the analysis of measured vibrations, the criteria of ISO 18816 and its six different parts are taken as acceptance criteria:

- Part 1: General guidelines.

- Part 2: Large steam turbine generator sets on land exceeding $50 \mathrm{MW}$.

- Part 3: Industrial machines with nominal power greater than $15 \mathrm{~kW}$ and rated speeds between $120 \mathrm{r} / \mathrm{min}$ and $15000 \mathrm{r} / \mathrm{min}$ when measured in situ.

- Part 4: Sets powered by gas turbines, excluding aircraft derivatives 
- Part 5: Sets of machines in hydraulic generating and pumping plants.

- Part 6: Reciprocal machines with nominal powers greater than $100 \mathrm{~kW}$.

In order to evaluate the vibrations measured in the propulsion lines of the ships, ISO 108163[2] standards are adopted for gearboxes, support points and bearings and ISO 10816-6 [1] for the evaluation of propulsion engines.

The norm ISO 10816-3 [2] establishes criteria for the levels of the linear vibrations measured according to the power, revolutions per minute of rotation and type of support or anchoring of the equipment (flexible, rigid or semi-rigid).

The norm ISO 10816-6[1] classifies the vibration of the machinery in seven levels. The standard does not indicate how to classify the machinery that is being measured. It only indicates that as an example many industrial and marine Diesel engines are classified 5, 6 and 7. But it does not give more details. Manufacturers of marine engines such as Wartsilla and MTU give a rating of 5 to their engines.

\section{Measured Data}

Between 2013 and 2018, more than 150 diesel combustion engines from different manufacturers and models have been vibrated. The following is a summary of the brands and models of diesel combustion engines serviced.

Table 1. Summary of Brand and Model of Diesel Engines serviced.

\begin{tabular}{l}
\hline \multicolumn{1}{c}{ BRAND - MODEL } \\
\hline MTU - 12V M70 \\
\hline MTU - 1163 TB93 \\
\hline CATERPILLAR - 3412 \\
\hline CATERPILLAR - 3056 \\
\hline CATERPILLAR - C18 \\
\hline DETROIT DIESEL - 6L 2T \\
\hline DETROIT DIESEL - 6L 71T \\
\hline DETROIT DIESEL - 16-645 E2 \\
\hline MAN B\&W - 6L23/30A \\
\hline CUMMINS \\
\hline
\end{tabular}

The values of the vibration measurements were taken in the diesel combustion engines according to ISO 10816-6 [1].

Fig. 1. Diesel engine in L.

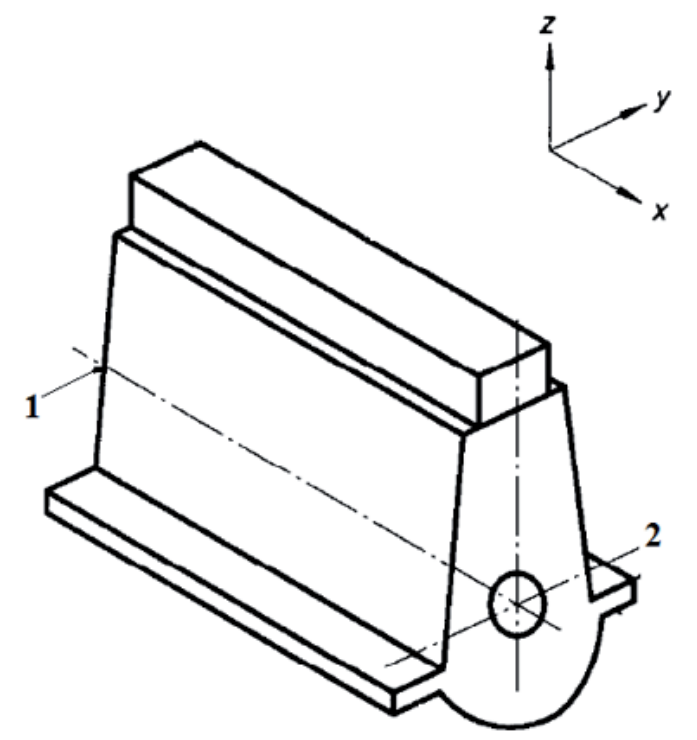

Fig. 2. Multi-cylinder Diesel engine in V.

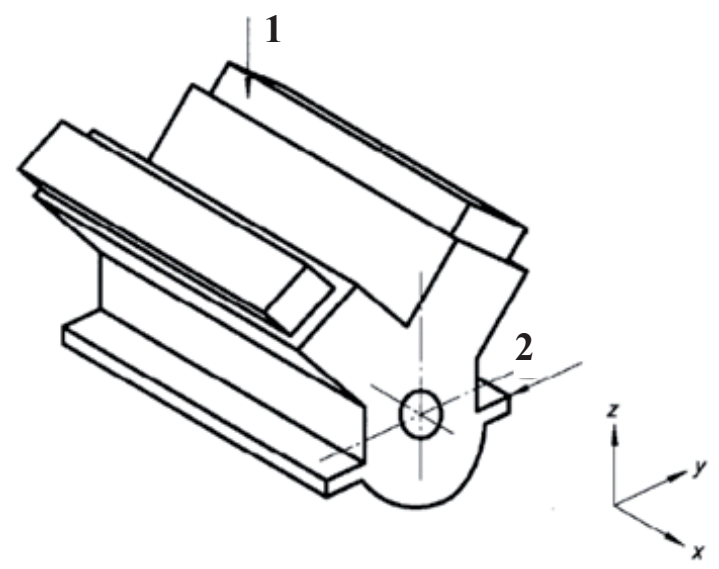

Points 1 and 2 are called free side and side coupling respectively. At each point the measurement is made in the three directions Vertical (V), Horizontal $(\mathrm{H})$ and Axial $(\mathrm{A})$.

The data taken is compared with the classifications and acceptable levels given in ISO 10816-6 [1]. 
Fig. 3. Comparison of global vibration values with the acceptance criteria according to ISO 10816-6.

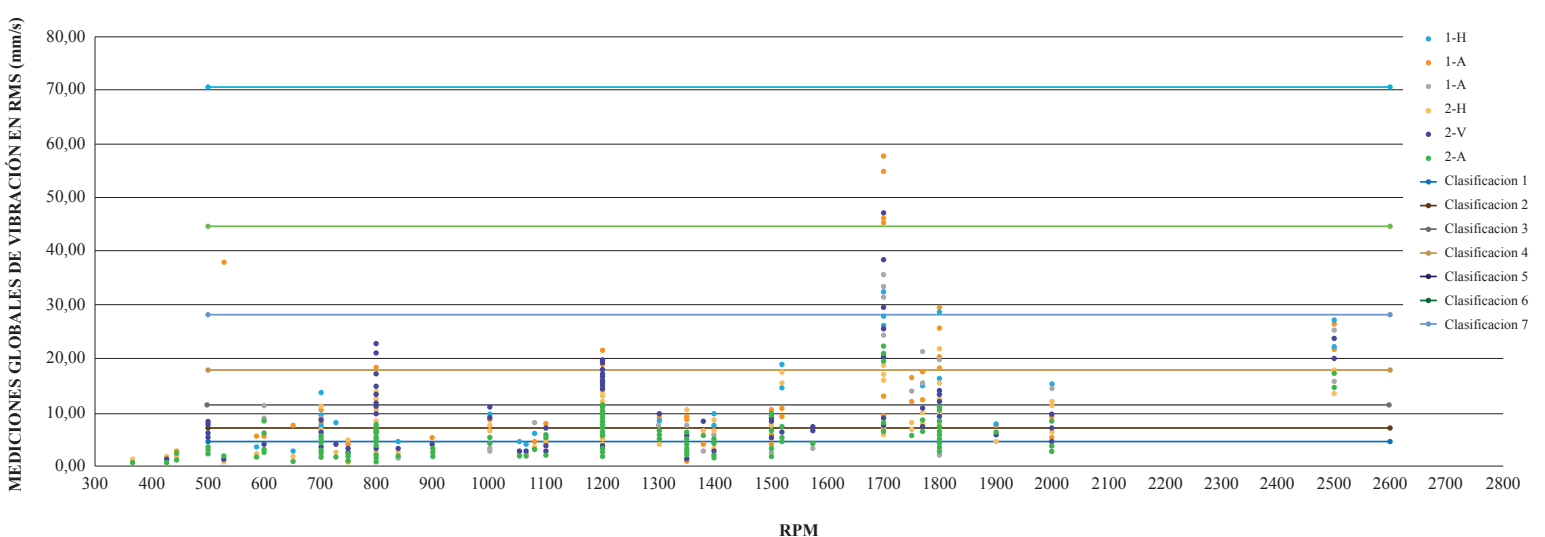

Fig. 4. Comparison - Values Of Global Vibration Vs Classification Levels - Motors Without Failure.

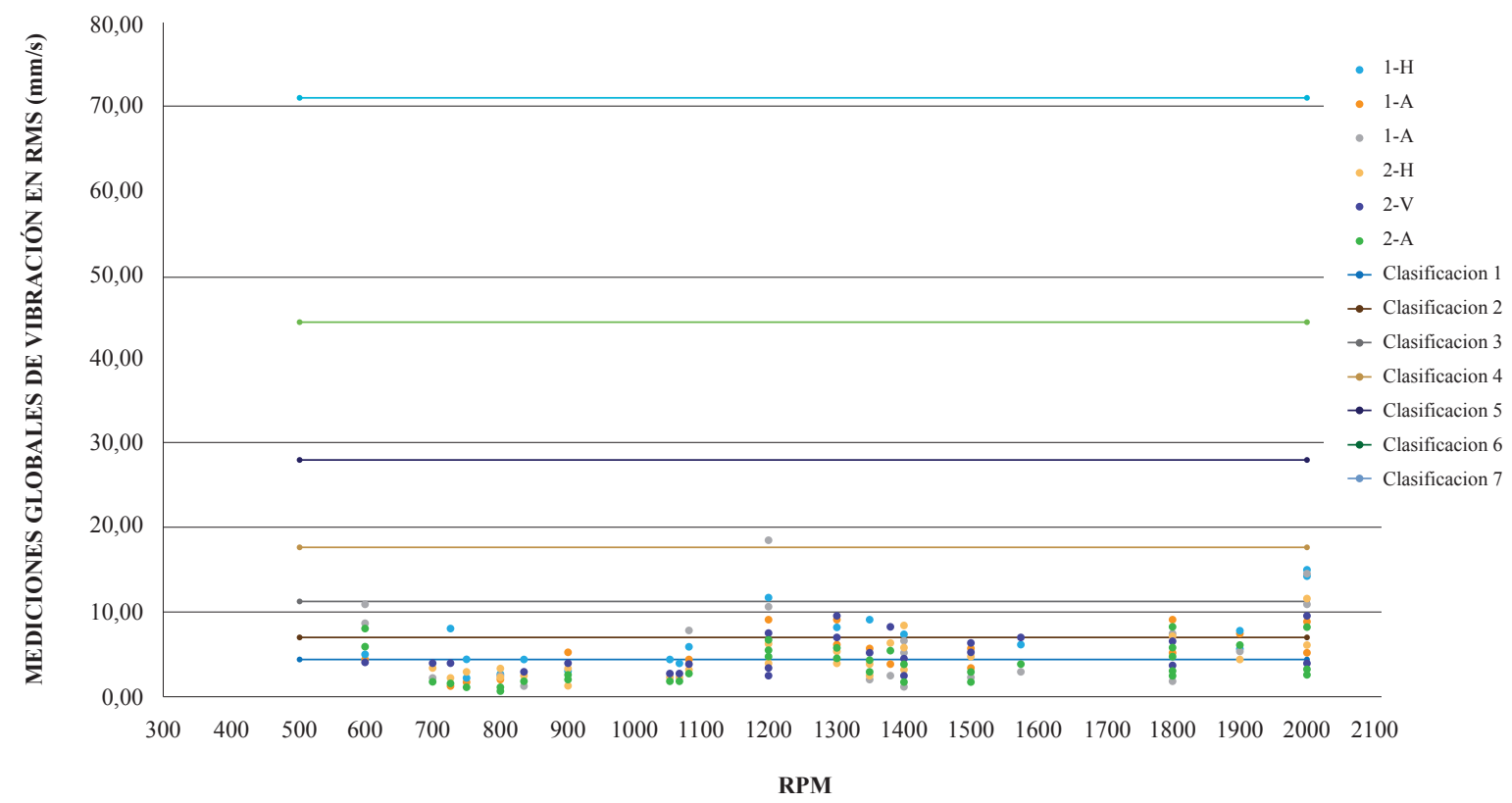

For the analysis, 23 vessels were taken into account, each of which possesses two propulsion lines, so in total 46 engines were examined. As shown in illustration 6 , of the $48 \%$ of the ships to which the global vibration measurements were taken, their engines present failure even with vibration magnitudes below the classification 5 indicated in ISO 10816-6 [1]. These failures are related to sources other than poor installation or misalignments of engine parts, such as high levels of cooling water temperature or low oil pressure, associated with a lack of maintenance.

If marine diesel engines continue to be evaluated under ISO 10816-6[1] in the considerations that this indicates, failures could arise due to an erroneous decision, for example a propulsion engine could be presented with vibration levels 
Fig. 5. Comparison - Global Vibration Values Vs Classification Levels - Faulty Engines.

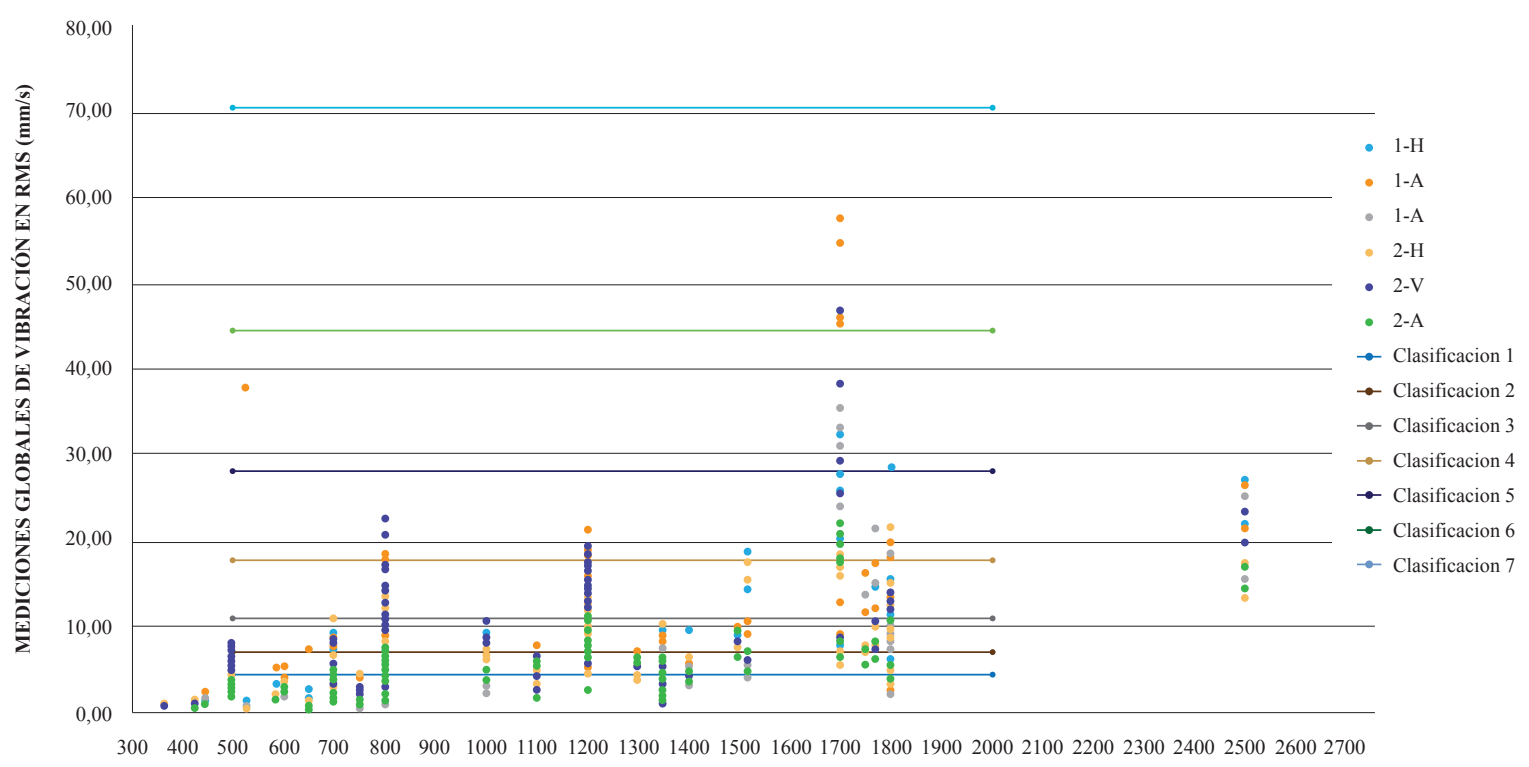

RPM

Fig. 6. Comparison - Global Vibration Values Vs Classification Levels - Faulty Engines with Values below the Qualification 5.

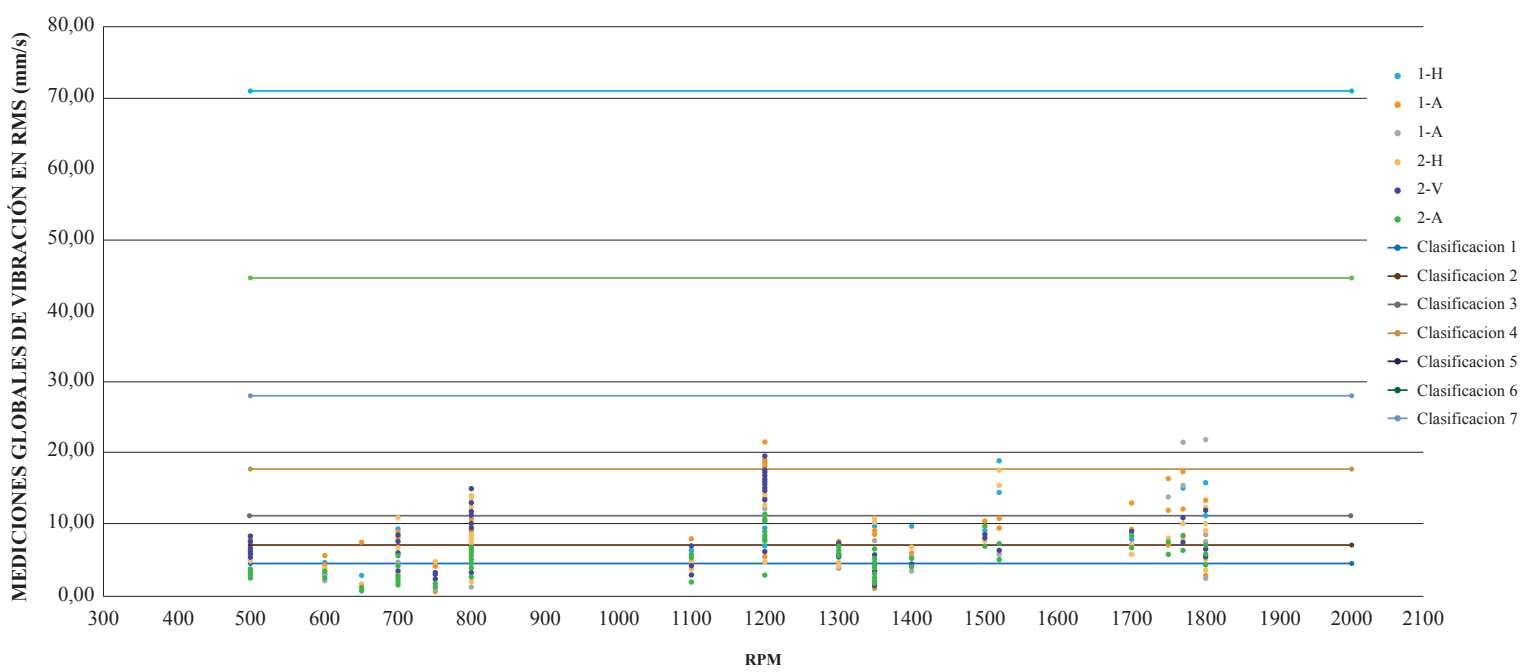

above the classification 4 that was affecting the structural integrity of the vessel. Or have a diesel combustion engine whose levels of vibration were above classification 5 but that did not present problems of mechanics, simply the base where it is supported is flexible and the material of the vessel is made of aluminum or composite material.

\section{Conclusion}

There are engine failures, even if these have global vibration levels below the minimum classification suggested by ISO 10816-6[1], so the classification indicated by ISO 10816-6[1] should be modified, the standard should have the ability to indicate, as is 
the norm ISO 10816-3[2], the levels of acceptance according to their power, the type of anchoring of the engines, whether rigid or flexible and also the construction material of the vessel.

The way of obtaining the accepted levels of vibration for marine diesel engines could be in two ways:

- Establish a list of the linear vibration levels in Diesel internal combustion engines installed in new vessels, tabulating power, number of banks (1 or 2), propulsion line numbers, type of anchoring of the bases (Flexible, Rigid or Semi-rigid) ) and material of the vessel (Steel, Aluminum or Composite Materials) and create a tendency to depart from said primary values by handling a first alarm (Caution) of $25 \%$ of the initial value.

- Set up a list of linear vibration levels in diesel internal combustion engines after maintenance tabulating power, number of benches (1 or 2 ), propulsion line numbers, type of anchoring of the bases (Flexible, Rigid or Semi-rigid) and material of the vessel (Steel, Aluminum or Composite Materials) and register the vibration values when the operating parameters
(Temperature, Pressure) exceed the alarm value. This is because for the vibration levels to be considered high or harmful, it is because the machinery is suffering some affectation reflected in its temperature and operating pressure of Oil, Fuel, Cooling Water.

With these values of vibration lines would be created more real acceptance levels and would help to make a more assertive diagnosis to diesel propulsion engines.

\section{References}

1. ISO. (15 de Diciembre de 1995). ISO 10816-6. Mechanical vibration -- Evaluation of machine vibration by measurements on non-rotating parts -- Part 6: Reciprocating machines with power ratings above $100 \mathrm{Kw}$.

2. ISO. (15 de Mayo de 1998). ISO 108163. Mechanical vibration - Evaluation of machine vibration by measurements on nonrotating parts - Part 3: Industrial machines with nominal power above $15 \mathrm{~kW}$ and nominal speeds between $120 \mathrm{r} / \mathrm{min}$ and $15000 \mathrm{r} / \mathrm{min}$ when measured in situ. 